\title{
|JUSTIÇA JUVENIL, GUERRA ÀS DROGAS E DIREITOS HUMANOS: A EFETIVIDADE DO PRINCÍPIO DA EXCEPCIONALIDADE DA MEDIDA SOCIOEDUCATIVA DE INTERNAÇÃO
}

\author{
JUVENILE JUSTICE, WAR ON DRUGS, AND HUMAN RIGHTS: THE EFFECTIVENESS OF THE \\ PRINCIPLE OF THE EXCEPTIONALITY OF THE CORRECTIONAL MEASURE OF INCARCERATION
}

Gustavo Raposo Pereira Feitosa ${ }^{1}$ Acássio Pereira de Souza²

Resumo: Esta investigação versa sobre a aplicação reiterada pela Justiça Juvenil da medida socioeducativa de internação em face do ato infracional análogo ao tráfico de drogas no Brasil. Tal tratamento levou o Superior Tribunal de Justiça (STJ) a editar a Súmula n. 492/2012, a qual afirma que o tráfico de drogas, por si só, não deve ensejar obrigatoriamente a aplicação da referida medida socioeducativa, haja vista se tratar de ato infracional sem violência ou grave ameaça à pessoa. A análise sobre as razões desse tratamento envolve a investigação sobre o discurso da Guerra às Drogas e da denominada Doutrina Menorista em face do ato infracional análogo ao tráfico de drogas e a sua repercussão na violação à liberdade de locomoção assegurada a crianças e adolescentes pelos normativos nacionais e internacionais. $O$ estudo ocorreu por meio de pesquisa bibliográfica e documental, bem como por meio de metodologia quantitativa. Investigou-se a jurisprudência dos 26 Tribunais de Justiça dos estados e do Tribunal de Justiça do Distrito Federal e dos Territórios, entre as datas de 01 de janeiro de 2012 e 31 de dezembro de 2014. Verificou-se nas decisões estudadas a prevalência de fundamentos atinentes ao discurso da Guerra às Drogas e à Doutrina Menorista no tratamento jurisdicional do tráfico de drogas, em detrimento da efetividade do Princípio da Excepcionalidade e dos direitos humanos na aplicação da medida socioeducativa de internação.

Palavras-chave: Ato infracional análogo ao tráfico. Guerra às Drogas. Medida de internação. Súmula 492/STJ. Liberdade de locomoção.

\footnotetext{
1 Doutor em Ciências Sociais pela Unicamp; Mestre em Sociologia pela Universidade Federal do Ceará; Professor Titular no Programa de Pós-Graduação em Direito Constitucional da Universidade de Fortaleza; Av. Washington Soares, 1321, Edson Queiroz, 60811-905, Fortaleza, Ceará, Brasil; gfeitosa@unifor.br; https://orcid.org/0000-0002-3766-0112

2 Graduado em Direito pela Universidade Federal do Ceará; Pós-graduando em Direito Processual Penal pela Faculdade de Direito Prof. Damásio de Jesus; Assessor jurídico do Centro de Defesa da Criança e do Adolescente do Ceará; acassiopsouza@ gmail.com; https://orcid.org/0000-0002-7143-4362
} 


\begin{abstract}
This investigation is about the repeated application by Juvenile Justice of the correctional measure of incarceration in view of the infrational act analogous to drug trafficking in Brazil. Such decision led the Superior Court of Justice (STJ) to edit the Precedent n. 492/2012, which affirms that drug trafficking, by itself, should not make mandatory the application of this correctional measure, since it is an act without violence or serious threat to the person. The analysis of the reasons for this judicial treatment involves the research on the discourse of the War on Drugs and the so-called "Menorist Doctrine" in cases of infrational act analogous to drug trafficking and its repercussion on the violation of freedom of movement assured to children and adolescents by national regulations and international norms. The study was carried out through bibliographical and documental research, as well as through a quantitative methodology. We have investigated the jurisprudence of the 26 Courts of Justice of the states and the Court of Justice of the Federal District between the dates of January 1 ${ }^{\text {st }}, 2012$ and December 31 ${ }^{\text {st }}, 2014$. The prevalence of arguments based on to the speech of the War on Drug terms and on the "Menorist Doctrine" in cases related to drug trafficking was found in the decisions studied, to the detriment of the effectiveness of the Principle of Exceptionality and the human rights when the correctional measure of incarceration is applied.
\end{abstract}

Keywords: Infrational act analogous to drug trafficking. War on Drugs. Incarceration measures. Precedent 492 STJ. Freedom of movement.

\title{
Introdução
}

Os direitos humanos de crianças e adolescentes têm sido objeto de relevantes mudanças nas últimas décadas com a consagração da Doutrina da Proteção Integral como novo paradigma do tratamento jurisdicional desses segmentos. A Convenção Internacional dos Direitos da Criança da Organização das Nações Unidas (CIDC), promulgada no Brasil pelo Decreto n. 99.710/1990 (BRASIL, 1990a), o art. 227 da Constituição Federal de 1988 e o Estatuto da Criança e Adolescente (Lei Federal n. 8.069/1990 - ECA) inauguram a concepção de que crianças e adolescentes são detentores de todos os direitos fundamentais inerentes à condição humana, sem qualquer distinção de raça, cor, sexo, idioma, crença, opinião política, origem nacional, étnica, social, posição econômica ou qualquer outra condição da criança ou do adolescente, de seus pais ou de seus representantes legais.

No âmbito da responsabilização juvenil em face da infração de norma penal, tal mudança de paradigma expressa-se sobremodo na garantia do devido processo legal, na excepcionalidade da privação de liberdade e na consequente prevalência das medidas de responsabilização de meio aberto e do direito fundamental à convivência familiar e comunitária. A CIDC, em seu art. 37, alínea "b", determina que "nenhuma criança seja privada de sua liberdade de forma ilegal ou arbitrária" e que "a detenção, a reclusão ou a prisão de uma criança, será efetuada em conformidade com a lei e apenas como último recurso, e durante o mais breve período de tempo que for apropriado." No mesmo diapasão, as "Regras Mínimas das Nações Unidas para a Administração da Justiça, da Infância e da Juventude" (Regras de Beijing), de 1985, estabelecem como "princípios norteadores da decisão judicial das medidas", em seu artigo 17.1, alínea "a", que "as restrições à liberdade pessoal do jovem serão impostas somente após estudo cuidadoso e se reduzirão ao mínimo possível." Em seu art. 19.1, as Regras de Beijing dispõem que "a internação de um jovem em uma instituição será sempre uma medida de último recurso e pelo mais breve período possível." (DHNET, 2017). 
A Constituição Federal de 1988, seguindo o paradigma dos normativos internacionais, em seu art. 227, $₫ 3^{\circ}$, inciso V, consagra os princípios da Excepcionalidade, da Brevidade e do Respeito à Condição Peculiar de desenvolvimento de crianças e adolescentes quando da aplicação de medida de privação de liberdade. ${ }^{3}$ Ademais, o "caput" do referido artigo constitucional estabelece o direito à liberdade e o direito à convivência familiar e comunitária como direitos fundamentais a serem assegurados, com prioridade absoluta, pelo estado, pela sociedade e pela família. $O$ \2 do art. 122 do ECA determina, ainda, que "em nenhuma hipótese será aplicada a internação, havendo outra medida adequada" (BRASIL, 1990b), assinalando o caráter residual da privação de liberdade na sistemática da Doutrina da Proteção Integral.

No que toca ao tratamento jurisdicional do ato infracional análogo ao tráfico de drogas, entretanto, verifica-se a não efetividade desses direitos e garantias fundamentais no Brasil. A pesquisa publicada pelo Conselho Nacional de Justiça (CNJ) no ano 2012, intitulada Panorama Nacional: a Execução das Medidas Socioeducativas de Internação, apontou que o ato infracional análogo ao tráfico de drogas é a segunda maior causa de aplicação de medida socioeducativa de internação no Brasil. Conforme tal pesquisa, o tráfico representa a causa de $24 \%$ das internações de adolescentes no País, atrás apenas do ato infracional análogo ao roubo, com 36\% (BRASIL, 2012).

No mesmo diapasão, o Levantamento Nacional do Atendimento Socioeducativo ao Adolescente em Conflito com a Lei, publicado pelo Ministério de Direitos Humanos em 2018, indicou a seguinte ordem dos atos infracionais que mais ensejam a aplicação da medida de internação no Brasil no ano 2016: 1. Roubo (12. 960 adolescentes - 47\%); 2. Tráfico (6.254 adolescentes - 22\%); 3. Homicídio (2.730 adolescentes - 10\%); 4. Furto (894 adolescentes - 3\%) (MINISTÉRIO NACIONAL DE DIREITOS HUMANOS, 2018). O número de adolescentes internados por tráfico, 6.254, supera em quase três vezes o número de adolescentes internados por homicídio, que é a terceira causa de internação no Brasil.

No presente trabalho buscou-se investigar as razões que conduzem a Justiça Juvenil a conferir tratamento reiteradamente excepcional ao ato infracional análogo ao tráfico de drogas no Brasil, já que este não possui em seus elementares a "grave ameaça ou a violência à pessoa". Tais atos, a priori, não ensejariam a aplicação da medida de privação de liberdade, consoante determinam os normativos internacionais e, especificamente, o rol taxativo do art. 122 do ECA, o qual dispõe sobre as hipóteses de aplicação da medida excepcional de internação. ${ }^{4}$

\footnotetext{
3 "Art. 227. É dever da família, da sociedade e do Estado assegurar à criança, ao adolescente e ao jovem, com absoluta prioridade, o direito à vida, à saúde, à alimentação, à educação, ao lazer, à profissionalização, à cultura, à dignidade, ao respeito, à liberdade e à convivência familiar e comunitária, além de colocá-los a salvo de toda forma de negligência, discriminação, exploração, violência, crueldade e opressão [...] $\int 3^{\circ}$ - O direito a proteção especial abrangerá os seguintes aspectos: [...] $\mathrm{V}$ - obediência aos princípios de brevidade, excepcionalidade e respeito à condição peculiar de pessoa em desenvolvimento, quando da aplicação de qualquer medida privativa da liberdade." (BRASIL, 1988).

4 Art. 122. A medida de internação só poderá ser aplicada quando: I - tratar-se de ato infracional cometido mediante grave ameaça ou violência a pessoa; II - por reiteração no cometimento de outras infrações graves; III - por descumprimento reiterado e injustificável da medida anteriormente imposta." (BRASIL, 1990b, grifo nosso).
} 
Em face desse contexto nacional de hiperinternação quando da prática de ato infracional análogo ao tráfico, o Superior Tribunal de Justiça (STJ) editou em 2012 a Súmula n. 492 que, assim, dispõe: "O ato infracional análogo ao tráfico de drogas, por si só, não conduz obrigatoriamente à imposição de medida socioeducativa de internação do adolescente." (SUPERIOR TRIBUNAL DE JUSTIÇA, 2012d). Consoante será apresentado ao longo da presente investigação, o impacto de referida Súmula parece ainda não ser suficiente para fazer frente às razões que continuam conduzindo a Justiça Juvenil a desferir tratamento arbitrário contra esse ato infracional.

Uma das hipóteses da presente investigação consiste na construção histórica do discurso da Guerra às Drogas e na sua conjugação com a permanência do caráter tutelar e segregatório da denominada Doutrina Menorista e de suas legislações pertinentes (Código de Menores de 1927 e Código de Menores de 1979) no tratamento jurisdicional dos adolescentes em conflito com a lei. ${ }^{5}$ De fato, o encontro da política da Guerra às Drogas e de suas implicações no recrudescimento do sistema de controle sociopenal (e socioinfracional) com o tratamento ainda tutelar da Justiça Juvenil emerge como totalidade discursiva capaz de produzir uma prática jurisdicional marcadamente arbitrária e punitivista.

Abordou-se, brevemente, a construção histórica do discurso da Guerra às Drogas nos Estados Unidos e a sua reverberação na América Latina nas últimas décadas, ressaltando o impacto que a criminalização das drogas vem causando na política criminal brasileira. Desse modo, destacouse o recrudescimento do sistema punitivo nas últimas décadas e de que modo esse recrudescimento se manifesta no tratamento jurisdicional e legislativo de exceção do tráfico de drogas em todo o Continente Americano. Em seguida, analisou-se a tutela jurisdicional do adolescente infrator da norma penal, à luz do ECA, da Constituição Federal de 1988 e dos documentos internacionais destinados à proteção integral de crianças e adolescentes.

Por fim, investigou-se a jurisprudência dos 27 Tribunais de Justiça dos Estados e Distrito Federal, no espaço de tempo entre 01 de janeiro de 2012 e 31 de dezembro de 2014. No total da pesquisa, foram analisados 796 acórdãos a partir de questionário contemplando variáveis destinadas a delinear de que modo cada acórdão representa tratamento excepcional em relação à sistemática de responsabilização do ECA e à manifestação do discurso da Guerra às Drogas.

Os dados coletados compuseram um banco de dados que foi analisado com a ajuda do software SPSS (Statistical Package for Social Sciences), com o escopo de aprofundar a análise

\footnotetext{
5 A denominada Doutrina Menorista, que ideologicamente fundamenta as legislações destinadas a crianças e adolescentes anteriores à Constituição de 1988 e à Lei Federal n. 8069/1990 no Brasil, constitui um conjunto de princípios e diretrizes normativas e jurisdicionais que concebem crianças e adolescentes como objeto processual, e não como sujeitos de direito. Tal Doutrina era marcada pelo tratamento discriminatório e arbitrário contra crianças e adolescentes das classes subalternas, os quais eram denominados "Menores", sendo a institucionalização total desse segmento uma de suas principais repercussões no âmbito fático, seja pela prática de atos que conflitavam com a lei, seja em razão da condição socioeconômica de suas famílias e comunidades. Para saber mais, ver: Pinheiro (2006).
} 
jurisprudencial por meio de metodologia quantitativa. ${ }^{6}$ As referidas variáveis foram construídas a partir de elementos caracterizadores da repercussão de um discurso criminalizante sobre o comércio ilícito de drogas, como a "reprovabilidade social do tráfico"; a "gravidade abstrata do crime de tráfico" e sua "hediondez"; a "proteção da sociedade e da ordem pública"; e a aplicação da Súmula 492 do STJ no período analisado.

Ademais, embora não seja o objeto específico da presente investigação, existem variáveis que permitirão perceber a evocação de conceitos que remetem ao tratamento tutelar e autoritário da Doutrina Menorista, para justificar tratamento severo em face do ato infracional análogo ao tráfico de drogas, como o entendimento de que a internação seria a "mais adequada para a ressocialização do adolescente", e não como medida excepcional; e a "flexibilização do rol taxativo do art. 122 do ECA", que traz as hipóteses de aplicação da medida de internação.

\section{Breves apontamentos sobre a política de guerra às drogas}

A análise da atual política criminal das drogas no Brasil exige a compreensão das motivações sociopenais e geopolíticas que nas últimas décadas inseriram a guerra ao tráfico de drogas numa estratégia econômica, política e militar dos Estados Unidos da América. Para Batista (1990, p. 11), o discurso da Guerra às Drogas engendrado nos Estados Unidos nas décadas de 1960 e 1970 conformou na atualidade um "discurso político-jurídico transnacional" que cumpre a função ideológica de ocultar as relações de poder que movimentam a economia global da droga no final do século XX.

Desse modo, para Batista (1997, p. 130), a política criminal de drogas no Brasil relaciona-se de modo dependente com a política criminal de drogas desenvolvida internacionalmente pelos países do centro do capitalismo, especialmente pelos Estados Unidos. Nas últimas décadas, tal política internacional se constituiu como uma expressa declaração de guerra contra o tráfico e as suas múltiplas representações políticas e econômicas. Tem-se, assim, a caracterização de uma política criminal norte-americana que vem se fundamentando na guerra como método e que se reverbera na política criminal brasileira. ${ }^{7}$

Para Batista (2003, p. 81), o problema da droga e do seu tratamento jurídico-penal na América Latina situa-se historicamente em dois níveis, econômico e ideológico. Há, para a autora, uma determinação estrutural na economia de mercado que emerge como força motriz

\footnotetext{
$\overline{6}$ Utilizou-se no estudo a metodologia da análise da jurisprudência por método quantitativo aplicado originariamente pelo grupo de pesquisa Justiça em Transformação (JET), liderado pelos professores Gustavo Raposo Pereira Feitosa e Daniela Passos. O grupo vem utilizando e aprimorando essa forma da análise de conteúdo em decisões judiciais, portais eletrônicos e documentos oficiais.

7 Batista (1997, p. 130) problematiza os desdobramentos dessa política de guerra: "De fato, se olharmos o atual cenário americano, que política criminal é essa que contempla operações militares em territórios estrangeiros, que distingue grupos aliados e beligerantes, promove acumulação e intercâmbio de informações em plano internacional e intervenção permanente da rede diplomática, administra orçamentos astronômicos, celebra crescentemente tratados que versam desde compromissos criminalizadores, até erradicação de culturas e extradições, passando por patrulhas marítimas e helicópteros, e na qual se pretende envolver a cada dia mais intensamente as forças armadas?"
} 
no desenvolvimento do mercado da droga, concomitante a uma carga ideológica e emocional que forja o "mito da droga" e uma consequente resposta autoritária do sistema jurídico-penal. A autora assinala que o neoliberalismo passa a estabelecer uma relação "esquizofrênica" com as drogas, uma vez que, por um lado, estimula a produção, comercialização e circulação da droga, em face de sua hiperlucratividade no mercado internacional, e, por outro lado, passa a construir um "arsenal jurídico e ideológico" de "demonização" e criminalização da droga.

Outra dimensão do discurso ideológico de Guerra às Drogas na América Latina diz respeito à confecção de um novo inimigo político-jurídico que justifique o prolongamento da geopolítica bélica norte-americana nas últimas décadas do século XX. O contexto de fim da Guerra Fria ensejou a necessidade de redefinição das prioridades de segurança nacional nos Estados Unidos. Conforme assinalam Feitosa e Pinheiro (2012), a legitimidade ou não das demandas por manutenção de efetivos e gastos militares dependia da capacidade de identificar um novo "inimigo" que exigisse constante e intensa atenção, ao ponto de justificar, inclusive, o emprego das forças militares: "o Pentágono, tradicionalmente, resistia ao emprego de militares em atividades típicas de combate ao crime, contudo, vislumbrou na ação internacional antidrogas uma possibilidade de preservar parcelas do orçamento para a defesa." (FEITOSA; PINHEIRO, 2012, p. 70).

Para Zaffaroni (2007, p. 51), há uma pressão geopolítica dos governos norte-americanos sobre as ditaduras latino-americanas para que estas declarem guerra à droga em seus territórios e no âmbito continental, com fundamento no discurso da política de segurança nacional. Verifica-se, então, uma evidente construção ideológica que visa à substituição dos inimigos dos Estados Unidos da América: "com a queda do muro de Berlim, torna-se necessário eleger outro inimigo para justificar a alucinação de uma nova guerra e manter níveis repressivos elevados. Para isso, reforçou-se a guerra à droga." (ZAFFARONI, 2007, p. 51). A redefinição de inimigos passa a legitimar interferências diplomáticas e militares dos Estados Unidos em diversos países da América Latina.

Em face da construção do novo inimigo a ser combatido, os responsáveis pela produção e pelo mercado das drogas, em especial a figura do traficante que se localiza na escala terminal de tal mercado, passam a ser "demonizados" e estereotipados com a etiqueta daquilo que há de estigmatizante na sociedade ocidental, como forma de legitimar a exceção do tratamento penal que lhe será conferido enquanto inimigo.

Ante o cenário de guerra e de delimitação do novo inimigo político-jurídico, a repressão contra o comércio ilícito drogas passa a ser prioridade premente dos sistemas punitivos norte-americanos e latino-americanos a partir das décadas de 1970 e 1980. Tal prioridade punitiva materializa-se na defesa de condenações rigorosas, de legislações severas em matéria de droga, de encarceramento em 
massa, de redução de garantias individuais e de estigmatização dos criminalizados, principalmente quando o tratamento punitivo se dirige aos sujeitos da cadeia terminal do mercado da droga. ${ }^{8}$

O Texto Constitucional de 1988, não obstante consagre vasto rol de direitos e garantias individuais, sofre a reverberação da política de Guerra às Drogas que se intensifica na América Latina nas décadas de 1970 e 1980. Em seu artigo 5º inciso XLIII, a Constituição confere ao tráfico ilícito de entorpecentes o mesmo tratamento despendido aos crimes de tortura e terrorismo, equiparandoos aos crimes hediondos. ${ }^{9}$ Em seguida, no ano 1990, é promulgada a Lei de Crimes Hediondos (Lei n. 8.072 de 1990) (BRASIL, 1990c), que acaba por proibir o indulto e a liberdade provisória para o crime de tráfico e, ainda, dobra os prazos processuais, com o escopo de ampliar o tempo da prisão provisória.

No ano 2006, foi promulgada a nova Lei de Drogas, a Lei n. 11.343/2006, que instituiu o Sistema Nacional de Políticas Públicas sobre Drogas (SISNAD) e que, em seu art. 33, tipifica o ato ilícito de tráfico de drogas ${ }^{10}$ (BRASIL, 2006b). O ponto mais sensível da nova Lei de Drogas, expresso em seu art. $28, \$ 2^{\circ}$, refere-se ao critério discricionário utilizado pela autoridade judicial para determinar se o dolo da pessoa apreendida com drogas é de uso ou é de tráfico. ${ }^{11}$

\section{0 tratamento jurisdicional do adolescente em conflito com a lei à luz do Estatuto da Criança e do Adolescente (Lei n. 8.069/1990)}

O ECA, em conformidade com os normativos internacionais e com o art. 227 do Texto Constitucional de 1988, representa uma nova sistemática de responsabilização do adolescente quando da prática de ato infracional. A emergência da Doutrina da Proteção Integral, ${ }^{12}$ ao alçar

\footnotetext{
8 O desenvolvimento e os efeitos da guerra às drogas dentro dos Estados Unidos também podem ser interpretados a partir de uma reflexão sobre o racismo e a segregação. O livro The New Jim Crow, de Michele Alexander, desenvolve uma importante análise sobre como a política de guerra às drogas incidem diretamente sobre as populações afro-americanas e latinas, criando um novo modelo de segregação racial. Como resultado desse processo, observa-se o encarceramento em massa de milhões de negros por delitos associados ao tráfico ou posse de drogas, a redução das famílias negras à miséria, a legitimação de legislação discriminatória contra ex-detentos, a privação do direito ao voto, entre outros efeitos excludentes (ALEXANDER, 2010).

9 "Artigo $5^{\circ}$, XLIII - a lei considerará crimes inafiançáveis e insuscetíveis de graça ou anistia a prática da tortura, o tráfico ilícito de entorpecentes e drogas afins, o terrorismo e os definidos como crimes hediondos, por eles respondendo os mandantes, os executores e os que, podendo evitá-los, se omitirem." (BRASIL, 1988).

10 Art. 33. Importar, exportar, remeter, preparar, produzir, fabricar, adquirir, vender, expor à venda, oferecer, ter em depósito, transportar, trazer consigo, guardar, prescrever, ministrar, entregar a consumo ou fornecer drogas, ainda que gratuitamente, sem autorização ou em desacordo com determinação legal ou regulamentar: [...] (BRASIL, 2006b).

11 Art. 28. Quem adquirir, guardar, tiver em depósito, transportar ou trouxer consigo, para consumo pessoal, drogas sem autorização ou em desacordo com determinação legal ou regulamentar será submetido às seguintes penas: [...) $\$ 2^{\circ}$ - Para determinar se a droga destinava-se a consumo pessoal, o juiz atenderá à natureza e à quantidade da substância apreendida, ao local e às condições em que se desenvolveu a ação, às circunstâncias sociais e pessoais, bem como à conduta e aos antecedentes do agente (BRASIL, 2006b, grifo nosso).

12 A Doutrina da Proteção Integral, que inspira a elaboração da Convenção Internacional dos Direitos da Criança da Organização das Nações Unidas (CIDC), de 1989, da Constituição Federal de 1988, especialmente de seu art. 227, e do Estatuto da Criança e do Adolescente (Lei Federal n. 8069/1990), representa a superação no campo normativo e jurisdicional da Doutrina Menorista, ao conceber crianças e adolescentes como sujeitos de direito autônomos e como pessoas em peculiar estágio de desenvolvimento. Diversos documentos internacionais são elaborados tendo como referencial principiológico a Doutrina da Proteção Integral: Regras Mínimas das Nações Unidas para Administração da Justiça da Infância e Juventude (Regras de Beijing), de 1985; Regras Mínimas das Nações Unidas para Jovens Privados de Liberdade, de 1990; Diretrizes das Nações Unidas para Prevenção da Delinquência Juvenil (Regras de Riad), de 1990. A Doutrina da Proteção Integral estabelece um conjunto
} 
crianças e adolescentes à condição jurídica de sujeito do processo, contribuiu decisivamente para o estabelecimento de um novo paradigma, o qual supera a lógica arbitrária, discricionária e subjetivista que impregnava a Doutrina da Situação Irregular, institucionalizada pelo Código de Menores de 1979.

Enquanto o Código de Menores de 1979 dispunha sobre um conjunto de situações genéricas que poderiam ensejar a aplicação de alguma medida restritiva de liberdade, o ECA destacase na seara infracional pela observância expressa do Princípio da Legalidade, por meio de seu artigo 103, que estabelece que, para a identificação de uma conduta infracional, esta deverá corresponder a uma figura típica descrita na lei como crime ou contravenção penal. ${ }^{13}$ Buscou-se afastar, destarte, os abusos discriminatórios tão marcantes nas legislações anteriores. $\mathrm{O}$ art. 112 do ECA traz o rol taxativo das medidas socioeducativas aplicadas em face da prática de ato infracional, ${ }^{14}$ sendo a medida de internação a sanção mais gravosa.

Em face de sua natureza extrema e segregadora, a medida socioeducativa de internação precisa observar os Princípios Constitucionais da Brevidade, da Excepcionalidade e do Respeito à Condição Peculiar do adolescente como pessoa em desenvolvimento, expressos no artigo 227, \3, inciso V, da Constituição Federal de 1988.

\subsection{A Taxatividade das hipóteses de Internação no artigo 122 do ECA}

A medida socioeducativa de internação possui hipóteses expressamente taxativas. 0 Princípio da Legalidade emerge como avanço normativo significativo da Doutrina da Proteção Integral para a superação das hipóteses vagas e discriminatórias que tão marcadamente constituíam os Códigos de Menores de 1927 e 1979. O Código de Menor de 1927, por exemplo, em seu art. 68, o qual dispunha sobre o menor de 14 anos autor de fato qualificado como crime ou contravenção penal, utiliza expressões como menor "abandonado", "pervertido" ou em "perigo de o ser" para definir a aplicação de uma medida que poderia configurar a privação de liberdade. O Código de Menores de 1979, em seu artigo 49, assevera que "o menor com desvio de conduta ou autor de infração penal poderá ser internado em estabelecimento adequado." A expressão "desvio de conduta", em face de seu caráter vago e discricionário, reproduz a tutela jurisdicional arbitrária que marca a Justiça Juvenil antes da promulgação da Constituição Federal de 1988 e do Estatuto da Criança e do Adolescente.

\footnotetext{
de direitos universais a todas as crianças e adolescentes. Para Pinheiro (2006, p. 81), a representação social de crianças e adolescentes como sujeitos de direito possui dois princípios fundantes: a "igualdade perante a lei" e o "respeito à diferença". 0 primeiro manifesta-se pela ideia de universalização dos direitos para todas as crianças e os adolescentes, superando a lógica de exclusão e segmentação inerentes à Doutrina Menorista, que se dirigiam como mecanismo de controle, disciplinamento e repressão social dos segmentos mais marginalizados socioeconomicamente.

13 Art. 103. "considera-se ato infracional a conduta descrita como crime ou contravenção penal." (BRASIL, 1990, p. 13563).

14 As medidas socioeducativas estão previstas no art. 112 do Estatuto da Criança e do Adolescente e são: I. Advertência; II. Obrigação de reparar o dano; III. Prestação de serviços à comunidade; IV. Liberdade assistida; V. inserção em regime de semiliberdade; VI. internação em estabelecimento educacional (BRASIL, 1990b).
} 
Com a emergência da Doutrina da Proteção Integral, não mais é concebível juridicamente a permanência de lacunas interpretativas e de subjetivismo na tutela jurisdicional do adolescente em conflito com a lei. Destarte, o art. 122 do ECA traz, taxativamente, as hipóteses de aplicação da medida excepcional de internação em estabelecimento socioeducacional. Liberati (2003, p. 117), ao se referir às hipóteses do art. 122 do ECA, é enfático: "o elenco das condições é taxativo e exaustivo, não havendo possibilidades de aplicação da medida fora das hipóteses apresentadas."

\subsection{Princípio da Excepcionalidade da privação de liberdade juvenil no Ordenamento Jurídico Brasileiro e no Direito Internacional}

O caput do art. 121 do ECA e o art. 227, \$3, inciso V, da Constituição Federal expressamente asseveram que o Princípio da Excepcionalidade constitui princípio inafastável na aplicação da medida socioeducativa de internação. No âmbito do Direito Internacional, a excepcionalidade da privação da liberdade do adolescente também é princípio expressamente reiterado. A Convenção Internacional dos Direitos da Criança, em seu art. 37, alínea "b", e as Regras de Beijing, em seu art. 17.1, alínea "a", estabelecem a aplicação de qualquer medida de privação de liberdade de crianças e adolescentes como último recurso da Justiça Juvenil. Ainda, as Regras Mínimas das Nações Unidas Para a Proteção dos Jovens Privados de Liberdade, de 1990, em seu art. 1º, assevera: "o sistema de justiça da infância e da juventude deverá respeitar os direitos e a segurança dos jovens e fomentar seu bem-estar físico e mental. Não deveria ser economizado esforço para abolir, na medida do possível, a prisão de jovens." (DHNET, 2017).

Conforme assinala Maior Neto (2006, p. 140), o princípio da excepcionalidade, quando se tratar da aplicação de medida socioeducativa que importe privação de liberdade, implica a imprescindibilidade da demonstração, de um lado, da imperiosa necessidade da medida mais severa, e, de outro, da justificativa, pormenorizada uma a uma, da inviabilidade ou inadequação das medidas em meio aberto em face do caso concreto. Nesse sentido, para o autor, seria eivada de nulidade a decisão judicial que impõe a aplicação da privação de liberdade de adolescente em conflito com a lei fundamentada apenas na gravidade do ato infracional ou no juízo meramente retributivo da medida socioeducativa.

Para Saraiva (2010), o Princípio da Excepcionalidade baseia-se na ideia de que a privação de liberdade, diante da sistemática de responsabilização do ECA, não se constitui na melhor opção para construção de uma ação socioeducativa efetiva. $\bigcirc$ autor é enfático ao cravar que "a privação de liberdade é um mal" e que seria falacioso assinalar que ela poderá representar um bem para o adolescente, enquanto mecanismo de defesa social que o é:

A privação de liberdade é um mal. Mal que até poderá ser necessário diante da incapacidade humana de desenvolver outra alternativa. Mas sempre um mal, cabendo aqui revisitar Foucault. A opção pela privação de liberdade resulta muito mais da inexistência de outra alternativa do que da indicação de ser esta a melhor 
dentre as alternativas disponíveis. Somente se justifica enquanto mecanismo de defesa social, pois não há nada mais falacioso do que o imaginário de que a privação de liberdade poderá representar em si mesma um bem para o adolescente a que se atribui a prática

de uma ação delituosa (SARAIVA, 2010).

No mesmo diapasão, Liberati (2003, p. 117) aduz que o Princípio da Excepcionalidade significa que a aplicação da medida extrema da privação de liberdade só deve ser aplicada quando for inviável ou quando malograr a aplicação das demais medidas do sistema de responsabilização do ECA. No caso concreto, sendo possível a aplicação de outra medida que possa substituir a internação, o juiz deverá aplicá-la, observando as disposições expressas nos incisos I e II do art. 122 do ECA quanto às hipóteses de aplicação da privação da liberdade.

\section{Hiperinternação e Súmula 492 do STJ}

Conforme exposto, a compreensão sobre a excepcionalidade da privação de liberdade do adolescente obrigou o legislador ordinário a estabelecer um rol taxativo de hipóteses para aplicação da medida de internação. No que toca à primeira hipótese de aplicação da internação (art. 122, inciso I, do ECA), quando se tratar de ato infracional cometido mediante "grave ameaça" ou "violência a pessoa", Saraiva (2010, p. 176) assinala que a "violência" e a "grave ameaça" devem integrar o tipo penal enquanto elementar. $\bigcirc$ autor utiliza exatamente o tráfico de entorpecentes como exemplo de ato infracional que não possui tais elementares em seu tipo penal correspondente. Para o autor, não haveria que se falar em violência ou grave ameaça no tipo penal do tráfico de entorpecentes, já que, embora crime hediondo, ele não contém as características exigidas pelo dispositivo legal.

No mesmo diapasão, Paula (2006, p. 44) assinala que o tráfico de entorpecentes expressa um dos exemplos mais claros da "prepotência jurídica" no direito infracional, uma vez que, efetivamente, a ação não é caracterizada pela violência ou grave ameaça, sendo possível a aplicação da internação somente quando da sua reiteração ou descumprimento de medida socioeducativa imposta anteriormente, nos termos exatos dos incisos II e III do artigo 122 do ECA. Para o autor, alguns julgadores, substituindo o próprio legislador, interpretam a "gravidade" da infração como indicativo de uma suposta "gravidade social", justificando ilegais decretos de privação de liberdade.

\subsection{Súmula n. 492 do Superior Tribunal de Justiça}

Em decorrência do expressivo número de juízes de $1^{a}$ instância e de Tribunais de Justiça que entendem ser possível a aplicação da medida de internação em face do ato infracional análogo ao tráfico de drogas, o Superior Tribunal de Justiça (STJ) editou a Súmula n. 492, publicada em 13 de agosto de 2012. Para os ministros Og Fernandes, Marco Aurélio Belizze, Laurita Vaz e Gilson Dipp, a privação de liberdade deveria ser encarada como medida extrema, quando há reiteração e dentro das 
hipóteses previstas em lei. Assim, a nova súmula serviria para estabelecer limites claros à possibilidade de internação de "menores" por ato infracional análogo ao tráfico de drogas (SUPERIOR TRIBUNAL DE JUSTIÇA, 2012c).

A Súmula 492 do STJ representou efetivamente um avanço para a justiça infracional na medida em que deu respaldo jurisprudencial aos juízes e tribunais que já não aplicavam a medida de internação nos casos envolvendo tráfico de drogas. Para Costa e Armanil (2014), a construção do entendimento do STJ para a edição de referida súmula baseou-se em julgados precedentes que assinalavam quatro diretrizes principais: 1 . $O$ ato infracional análogo ao tráfico de drogas é delito desprovido de violência ou grave ameaça a pessoa, não podendo ser enquadrado na hipótese do inciso I do art. 122 do ECA; 2. Respeito ao Princípio da taxatividade ou determinação taxativa; 3. Respeito ao Princípio da Brevidade da medida de internação; e 4. Respeito ao Princípio da Excepcionalidade da medida de internação.

Em relação à primeira diretriz, vale fazer referência a um dos votos do ministro Gilson Dipp no Habeas Corpus n. 213778/RJ:

Em que pese o ato infracional praticado pelo menor - equiparado ao crime de tráfico de drogas - ser revestido de alto grau de reprovação, tal conduta é desprovida de violência ou grave ameaça à pessoa. Demais disso, não se admite a aplicação de medida mais gravosa com esteio na gravidade genérica do ato infracional ou na natureza hedionda do crime de tráfico de drogas. (SUPERIOR TRIBUNAL DE JUSTIÇA, 2012a, grifo nosso).

Depreende-se de referido voto que a gravidade abstrata do tráfico não poderia ser evocada para determinar a privação de liberdade do adolescente acusado de ato infracional análogo ao tráfico. Do mesmo modo, a hediondez do crime de tráfico no ordenamento jurídico brasileiro não poderia ser esteio para a aplicação de medida socioeducativa mais gravosa.

No que tange ao respeito ao princípio da taxatividade ou determinação taxativa, vale mencionar trecho do voto da ministra Maria Thereza Assis Moura no Habeas Corpus 231459/PE:

Com efeito, a medida socioeducativa de internação possui suas hipóteses de cabimento taxativamente previstas no artigo 122 do Estatuto da Criança e do Adolescente (ato infracional praticado mediante grave ameaça ou violência à pessoa; reiteração no cometimento de outras infrações graves; ou por descumprimento reiterado e injustificável da medida anteriormente imposta), dentre as quais não se encontram os atos infracionais equiparados ao tráfico ilícito de entorpecentes e respectiva associação. (SUPERIOR TRIBUNAL DE JUSTIÇA, 2012b, grifo nosso).

A terceira e a quarta diretrizes identificadas por Costa e Armanil (2014) dizem respeito aos Princípios da Brevidade e da Excepcionalidade quando da aplicação da medida de internação trazidas no âmbito da Constituição Federal. A ministra Maria Thereza Moura, ao tratar da medida socioeducativa de internação, assinala, também no Habeas Corpus n. 231459/PE, que: 
Tal medida, prevista no artigo 121 do Estatuto da Criança e do Adolescente, por importar na privação da liberdade do adolescente, é albergada pelos princípios da brevidade, excepcionalidade e respeito à condição peculiar de pessoa em desenvolvimento, conforme disposição expressa no aludido dispositivo, bem como no artigo 227, parágrafo $3^{\circ}$, inciso $\mathrm{V}$, da Constituição Federal. Dentre os princípios apontados, destaca-se o da excepcionalidade, que assegura ao adolescente a inaplicabilidade da medida de internação quando houver a possibilidade de aplicação de outra menos onerosa ao seu direito de liberdade. É pacífico, perante esta Corte, o entendimento no sentido de que, não verificada nenhuma destas hipóteses, a medida de internação mostra-se incabível [...] (SUPERIOR TRIBUNAL DE JUSTIÇA, 2012b, grifo nosso).

Os Princípios da Brevidade e da Excepcionalidade emergem no entendimento do Tribunal Superior como princípios direcionados ao reconhecimento da condição peculiar de desenvolvimento do adolescente, afastando-se os graves danos que a privação da liberdade e do direito de ir e vir podem causar à formação do caráter e da subjetividade do adolescente acusado de ato infracional.

\section{Análise Jurisprudencial da repercussão da Política de Guerra às Drogas na Justiça Juvenil brasileira}

Nesta seção, serão analisadas as motivações e os fundamentos do processo de hiperinternação dos adolescentes acusados de ato infracional análogo ao tráfico de drogas no Brasil. Conforme se verificou a partir de pesquisa jurisprudencial, é recorrente a remissão a conceitos que se relacionam com o discurso da Guerra às Drogas e das legislações penais que incorporam sua política criminal, como o caráter "hediondo", a "gravidade abstrata", a "punição moral" e a "reprovabilidade social" da conduta do tráfico de drogas.

Tais conceitos são argumentos discursivos que, recorrentemente, fundamentam as decisões judiciais que determinam o encarceramento de adolescentes acusados de ato infracional análogo ao tráfico. Paralelamente à utilização desses conceitos imanentes ao discurso da Guerra às Drogas, as decisões judiciais utilizam-se, também, de conceitos da Doutrina Menorista para viabilizar a flexibilização dos dispositivos do ECA e justificar o tratamento de exceção conferido ao ato infracional análogo ao tráfico.

Tais conceitos expressam-se, por exemplo, na ideia de que a medida de internação se constituiria em "medida de proteção" ou em "medida mais adequada para a ressocialização" do adolescente em face de sua relação com o tráfico, e não como medida extrema e excepcional a violar o direito de locomoção. Passa-se, doravante, à análise da jurisprudência que trata do ato infracional análogo ao tráfico de drogas no contexto dos Tribunais de Justiça (TJs) do Brasil. 


\subsection{Metodologia da Pesquisa Jurisprudencial}

$\mathrm{Na}$ presente pesquisa jurisprudencial, foram analisados acórdãos de $2^{\mathrm{a}}$ instância do Poder Judiciário brasileiro que tratam da prática do ato infracional análogo ao tráfico de drogas. Pesquisaram-se a jurisprudência de 27 tribunais de justiça de todos os estados brasileiros e Distrito Federal, com o foco nas decisões que envolvem o adolescente em conflito com a lei e a prática do tráfico de drogas.

No que toca ao aspecto quantitativo da pesquisa, fez-se um levantamento numérico de todos os acórdãos publicados pelos Tribunais de Justiça entre 01 de janeiro de 2012 e 31 de dezembro de 2014. Ressalte-se que o ano 2012 foi adotado como referência por ser este o ano de promulgação da Lei n. 12.594/2012, que institui o Sistema Nacional de Atendimento Socioeducativo (SINASE), bem como por ter sido o ano em que foi editada a Súmula n. 492 do Superior Tribunal de Justiça.

No desenvolvimento da pesquisa, utilizaram-se as ferramentas de busca jurisprudencial dos sítios eletrônicos (sites) dos tribunais de justiça. Tal busca utilizou como critérios a data de publicação dos acórdãos e a busca por palavra-chave adequada à identificação de decisões que envolvam diretamente o ato infracional análogo ao tráfico de drogas. ${ }^{15}$ Desse modo, chegou-se ao número de 3.545 acórdãos envolvendo a prática de ato infracional análogo ao tráfico de drogas nos 26 tribunais estaduais e no Tribunal do Distrito Federal e Territórios. Os acessos aos sítios virtuais ocorreram entre 19 de janeiro de 2015 e 17 de maio de 2015. Por fim, a análise qualitativa dos dados gerais realizou-se por meio da escolha aleatória de 30\% das ementas das decisões coletadas de cada estado.

Ressalte-se, contudo, que nessa coleta de decisões houve entraves na completude de dados em determinados estados. Os Tribunais de Justiça dos estados do Ceará e do Pará, em decorrência das limitações dos seus sistemas de busca virtual, não apresentaram nenhum acórdão pertinente aos objetivos da presente pesquisa. Outros sistemas de busca aparentam não realizar a busca de forma devida, já que o número de decisões encontradas por meio das ferramentas dos sites foi bastante reduzido. ${ }^{16}$ Não obstante, essas limitações acarretarram pouco impacto no resultado geral da pesquisa, tendo em vista não serem estados com movimentação processual expressiva no tema.

A limitação do filtro de busca do Tribunal de Justiça do Estado de São Paulo representou, contudo, o maior impacto na presente pesquisa. Foram coletados 732 acórdãos nesse Estado. Ocorre que, quando da aplicação do instrumental com as variáveis de análise nesses acórdãos, todos se

\footnotetext{
$\overline{15}$ Em todos os 27 sites dos Tribunais do Brasil, a coleta quantitativa de decisões realizou-se utilizando o termo "Ato Infracional", sempre com o recurso das aspas, como palavra-chave de busca. Em seguida, foi realizada a busca nas decisões já destacadas dos termos "tráfico", "drogas" e "Súmula 492", para se chegar aos acórdãos que versavam sobre o ato infracional análogo ao tráfico de drogas.

16 Tribunal de Justiça do Matogrosso (TJMT): oito acórdãos; Tribunal de Justiça do Maranhão (TJMA): um acórdão; Tribunal de Justiça da Paraíba (TJPB): quatro acórdãos; Tribunal de Justiça do Piauí (TJPI): quatro acórdão; Tribunal de Justiça do Amazonas (TJAM): cinco acórdãos; Tribunal de Justiça do Rio Grande do Norte (TJRN): um acórdão; e Tribunal de Justiça de Roraima (TJRO): um acórdão.
} 
referiam a processos criminais, e não a processos de apuração de ato infracional, por limitações do sistema de busca. Desse modo, optou-se por excluir as decisões do Estado de São Paulo.

Após a aplicação dos critérios metodológicos de busca e da exclusão das decisões de São Paulo, chegou-se ao número de 796 acórdãos analisados, os quais representam a soma dos 30\% das decisões de cada estado. Nas seções seguintes, serão apresentadas as análises descritivas das variáveis para, em seguida, serem apresentados os cruzamentos das variáveis, como forma de aprofundar as análises sobre a repercussão do discurso da Guerra às Drogas no tratamento jurisdicional do ato infracional do tráfico.

\subsection{Panorama da jurisprudência}

Esta seção tem como escopo apresentar por meio de tabulações e gráficos os principais dados obtidos na pesquisa jurisprudencial a partir de variáveis unitárias. Posteriormente, por meio do software SPSS, será apresentado o cruzamento de variáveis, com o intuito de aprofundar a análise jurisprudencial. As variáveis unitárias buscarão verificar os seguintes aspectos: medida socioeducativa aplicada em cada decisão; fundamentação dos incisos do art. 122 do ECA nas decisões que aplicam a medida de internação; e remissão aos conceitos de "proteção da sociedade e da ordem pública", da "gravidade abstrata" e do "caráter hediondo" do crime de tráfico e de sua "reprovabilidade social". Sublinhe-se que a variável referente à aplicação da Súmula 492 do STJ será apresentada no tópico seguinte, o qual diz respeito ao cruzamento das variáveis.

\subsubsection{Medida socioeducativa aplicada em cada decisão}

Esta variável demonstra as medidas socioeducativas aplicadas em cada um dos 796 acórdãos analisados. Ela emerge como relevante para a hipótese desta pesquisa por apresentar um panorama geral das medidas aplicadas pelos TJs quando do cometimento de ato infracional análogo ao tráfico no Brasil.

Tabela 1 - Medidas socioeducativas aplicadas nas decisões analisadas

\begin{tabular}{lcc}
\hline Medida Socioeducativa & N. de Acórdãos & Porcentual \\
\hline Prestação de Serviço à Comunidade & 15 & 1,9 \\
Liberdade Assistida & 42 & 5,3 \\
Semiliberdade & 183 & 23,0 \\
Internação & 526 & 66,1 \\
Decisão não aplica medida socioeducativa ou informação indisponível & 30 & 3,8 \\
\hline Total & $\mathbf{7 9 6}$ & $\mathbf{1 0 0 , 0}$ \\
\hline Fonte: Os autores. &
\end{tabular}


Conforme exposto na Tabela 1, das 796 decisões analisadas, 66,1\% determinam a aplicação da medida de internação. Desse modo, demonstra-se que a privação da liberdade representa a principal das medidas aplicadas pela Justiça Juvenil diante do tráfico de drogas. A Liberdade Assistida (LA) foi a medida socioeducativa aplicada em apenas 5\% das decisões analisadas. A Prestação de Serviço à Comunidade (PSC) foi aplicada em apenas $2 \%$ das decisões. Tem-se, assim, que as medidas de meio aberto (PSC e LA) representam apenas 7\% das medidas socioeducativas aplicadas no âmbito da presente pesquisa.

\subsubsection{Quando se aplica a medida socioeducativa de internação, a que inciso do art. 122 a decisão faz referência?}

O art. 122 do ECA traz as hipóteses exaustivas de aplicação da medida excepcional de internação, a saber:

a) tratar-se de ato infracional cometido mediante grave ameaça ou violência a pessoa;

b) por reiteração no cometimento de outras infrações graves;

c) por descumprimento reiterado e injustificável da medida anteriormente imposta.

Essa variável, que diz respeito à identificação de qual inciso do rol taxativo do art. 122 do ECA a decisão analisada se baseou para a aplicação da internação, constitui um dos parâmetros-chave na caracterização do tratamento jurisdicional de exceção no âmbito dessa investigação. Ressalta-se que a análise das ementas considerou qualquer referência direta ou indireta às referidas hipóteses do art. 122 do ECA, e não apenas a remissão precisa aos dispositivos legais em si.

Tabela 2 - Quando se aplica a medida socioeducativa de internação, a que inciso do art. 122 a decisão faz referência?

\begin{tabular}{lcc}
\hline & N. Acórdãos & Porcentual \\
\hline Inciso I & 8 & 1,0 \\
Inciso II & 211 & 26,5 \\
Inciso III & 19 & 2,4 \\
Nenhum dos Incisos do art. 122 & 285 & 35,8 \\
Decisão não aplica medida de internação & 274 & 34,3 \\
\hline Total & $\mathbf{7 9 6}$ & $\mathbf{1 0 0 , 0}$ \\
\hline Fonte: OS autores. & &
\end{tabular}

Os dados da Tabela 2 evidenciam que há um tratamento jurisdicional excepcional da Justiça Juvenil quando do cometimento do ato infracional análogo ao tráfico de drogas: 35,8\% das decisões analisadas, que representam o quantitativo de 285 decisões, aplicam a medida extrema de 
internação sem fazer referência a nenhum dos incisos do art. 122 do ECA. Logo, não há parâmetro legal explícito que justifique a aplicação da medida de internação nessas decisões.

Os acórdãos que fazem referência aos incisos II e III, que, a priori, não flexibilizam o rol exaustivo do art. 122, representam, juntos, apenas 28,9\% das decisões analisadas. Ademais, a análise dessa variável demonstra outra ilegalidade flagrante: $1 \%$ das decisões analisadas, quer dizer, oito decisões, fundamentam a aplicação da medida de internação com base no inciso I do art. 122, o qual dispõe sobre os atos infracionais cometidos mediante violência ou grave ameaça a pessoa. Conforme exposto, a doutrina e a jurisprudência do STJ são uníssonas em caracterizar o ato infracional análogo ao tráfico como não possuidor de violência ou grave ameaça.

Além dos dados trazidos de modo direto por essa variável, quando se retiram de sua análise as decisões que não aplicam medida de internação (274 acórdãos) e se analisa apenas o quantitativo das decisões que aplicam tal medida (523 acórdãos), o resultado é ainda mais revelador sobre o impacto das decisões que não fazem referência aos incisos do art. 122 do ECA, conforme o Gráfico 1.

Gráfico 1 - Inciso do art. 122 que fundamenta a aplicação da medida de internação.

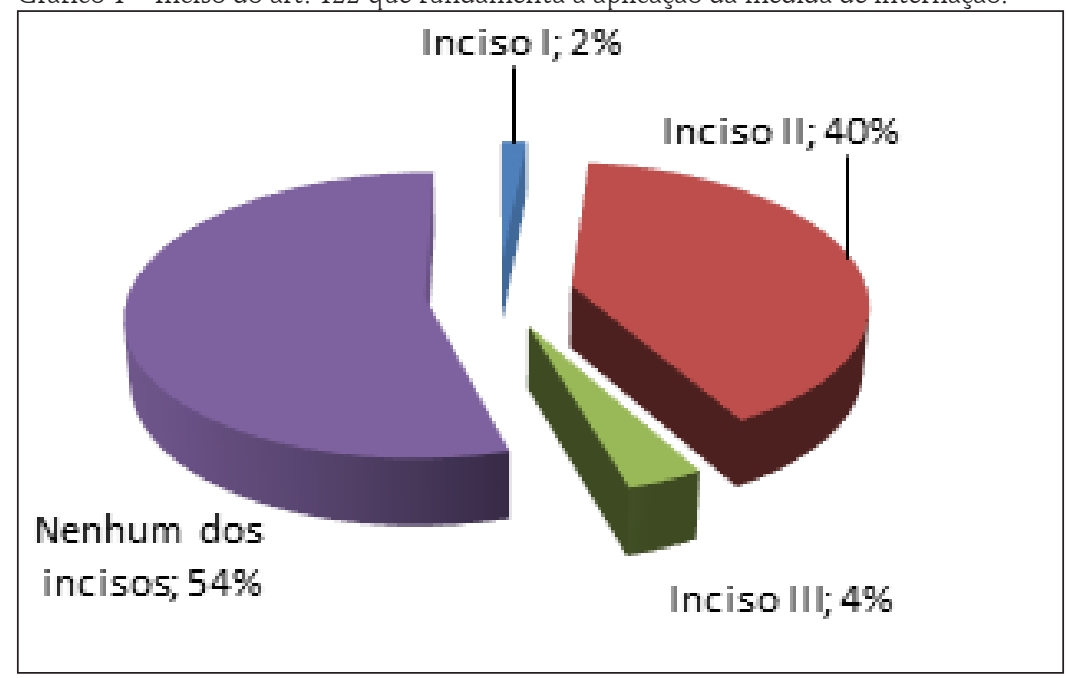

Fonte: os autores.

O Gráfico 1 demonstra que, quando da aplicação da medida de internação, 54\% das decisões (285 acórdãos) não fundamentam tal medida nas hipóteses trazidas pelos incisos do art. 122 do ECA. Esse dado significa que mais da metade das medidas de internação aplicadas no espectro da presente pesquisa são potencialmente ilegais. Ressalte-se que, se a fundamentação para a aplicação da medida de internação não está na lei, quais os fundamentos jurídicos, políticos e ideológicos que levam o Poder Judiciário brasileiro a tão reiteradamente aplicar uma medida considerada residual? A seção que traz o cruzamento de variáveis buscará delinear possível respostas para essa indagação. 


\subsubsection{Remissão à Proteção da Sociedade e da Ordem Pública e à Gravidade Abstrata do crime de tráfico na fundamentação das decisões}

A primeira variável desta subseção diz respeito à evocação da "proteção da sociedade e da ordem pública" para a segregação do adolescente acusado de ato infracional análogo ao tráfico de drogas. Tal variável representa uma dimensão relevante da identificação do discurso da Guerra às Drogas, uma vez que expressamente se dispensa a necessidade de uma resposta socioeducativa adequada ao adolescente para se afirmar um discurso discriminatório e punitivo de proteção da sociedade e da ordem pública. Vale sublinhar que as hipóteses do art. 122, conforme já apresentado, não fazem qualquer menção à ordem pública ou à proteção da sociedade como razão ou circunstância para a aplicação da medida de internação, não devendo ser evocada sequer como argumento secundário para o entendimento jurisdicional acerca do cabimento da privação de liberdade. $\mathrm{Na}$ Tabela 3 expressa-se o impacto dessa justificativa na aplicação da medida mais severa:

Tabela 3 - Decisão remete ao discurso da Proteção da Sociedade ou da Ordem Pública quando da aplicação da medida de internação?

\begin{tabular}{lcc}
\hline & N. Acórdão & Porcentual \\
\hline Sim & 122 & 15,3 \\
Não & 402 & 50,5 \\
Decisão que não aplica medida socioeducativa de internação & 274 & 34,2 \\
\hline Total & $\mathbf{7 9 6}$ & $\mathbf{1 0 0 , 0}$ \\
\hline Fonte: os autores. &
\end{tabular}

Fonte: os autores.

Observa-se que 122 decisões, que representam 15,3\% da totalidade, evocam a "proteção da sociedade e da ordem pública" na fundamentação para a aplicação da medida de internação. A Tabela 4, por sua vez, traz a variável da remissão à "gravidade abstrata" do crime do tráfico de drogas para a aplicação da medida de internação. A jurisprudência consolidada do STJ, que emergiu como precedente da Súmula 492/2012, assevera que a gravidade abstrata da infração penal não pode ser, em hipótese alguma, justificativa para a aplicação da medida de internação. A Tabela 4 expressa a remissão a essa variável:

Tabela 4 - Decisão evoca a Gravidade Abstrata do Tráfico quando da aplicação da medida de internação?

\begin{tabular}{lcc}
\hline & N. Acórdãos & Porcentual \\
\hline Sim & 325 & 40,8 \\
Não & 197 & 24,7 \\
Decisão que não aplica medida de internação & 274 & 34,4 \\
\hline Total & $\mathbf{7 9 6}$ & $\mathbf{1 0 0 , 0}$ \\
\hline Fonte: Os autores. & &
\end{tabular}

Verifica-se que $41 \%$ das decisões fazem remissão à gravidade abstrata do crime de tráfico de drogas, como fundamento para a adoção da medida mais rigorosa. Evidencia-se, assim, um 
número bastante expressivo de decisões que aplicam a internação (325 decisões) tendo como um dos parâmetros de justificativa essa variável. Ressalte-se que a gravidade conferida ao crime de tráfico de drogas emerge como uma das principais manifestações do discurso da Guerra às Drogas nas legislações penais e no seu tratamento jurisdicional.

\subsubsection{Remissão à Reprovabilidade Social e à Punição Moral ao tráfico de drogas nas decisões analisadas}

É recorrente no tratamento jurisdicional do tráfico de drogas a reprodução da condenação moral e da reprovabilidade social dessa conduta, como forma de justificar tratamento rigoroso por parte do sistema de justiça, ainda que implique o afastamento do juízo sobre o caso concreto e sua tipificação legal. No campo da Justiça Juvenil, já historicamente afeita às discricionariedades e subjetivismos do Estado-Juiz, tais parâmetros de análise tendem a se reverberar de modo ainda mais contundente. Nas Tabelas 5 e 6 demonstra-se o impacto dessas variáveis:

Tabela 5 - Decisão remete à Reprovabilidade Social do Tráfico quando da aplicação da medida de internação?

\begin{tabular}{lcc}
\hline & N. Acórdãos & Porcentual \\
\hline Sim & 68 & 8,5 \\
Não & 454 & 57,0 \\
Decisão que não aplica medida de internação & 274 & 34,4 \\
\hline Total & $\mathbf{7 9 6}$ & $\mathbf{1 0 0 , 0}$ \\
\hline Fonte: os autores. & & Porcentual \\
Tabela 6 - Decisão evoca a Punição Moral à atividade de tráfico quando da aplicação de medida? & 23,1 \\
\hline Sim & N. Acórdãos & 1 \\
Não & 184 & 42,5 \\
Decisão que não aplica medida de internação & 338 & 34,4 \\
\hline Total & 274 & $\mathbf{1 0 0 , 0}$
\end{tabular}

A Tabela 5 demonstra que 68 decisões da totalidade dos acórdãos analisados, que representam 8,5\%, remetem à "reprovabilidade social" do crime do tráfico para aplicar a medida socioeducativa de internação. A Tabela 6 evidencia que $23 \%$ das decisões evocam a "punição moral" sobre a atividade do tráfico de drogas para, do mesmo modo, aplicar a medida excepcional de internação. As duas variáveis ora analisadas expressam a repercussão do discurso de exceção construído sobre o tráfico de drogas no campo do sistema de justiça de modo geral. 


\subsubsection{Remissão à Hediondez do Crime do Tráfico nas decisões analisadas}

Essa variável tem como escopo analisar a repercussão do caráter hediondo do crime do tráfico de drogas nas decisões judiciais. O Texto Constitucional de 1988 e a Lei de Crimes Hediondos (Lei n. 8.072/1990), em clara reprodução do discurso da Guerra às Drogas então em emergência na América Latina no final dos anos 1980, equiparam o crime de tráfico de drogas aos crimes hediondos, junto de crimes de enorme gravidade e repercussão jurídica e política, como o crime de tortura e o crime de terrorismo.

$\mathrm{Na}$ Tabela 7 demonstra-se a repercussão dessa variável na totalidade das decisões ora analisadas.

Tabela 7 - Decisão remete à equiparação do crime do Art. 33 da Lei n. 11.343/06 a Crime Hediondo quando da aplicação da medida de internação?

\begin{tabular}{lll}
\hline & N. Acórdãos & Porcentual \\
\hline Sim & 116 & 14,6 \\
Não & 406 & 51,0 \\
Decisão que não aplica medida de internação & 274 & 34,4 \\
\hline Total & $\mathbf{7 9 6}$ & $\mathbf{1 0 0 , 0}$ \\
\hline Fonte: os autores. &
\end{tabular}

Observe-se que 14,6\% dos acórdãos remetem ao caráter hediondo do crime do tráfico de drogas para fundamentar a aplicação da medida de internação. Nos termos dos precedentes do STJ, conforme exposto, o caráter hediondo da infração penal não pode ser justificativa para a aplicação da medida socioeducativa de internação.

\subsection{Resultados de dados cruzados entre duas variáveis: aprofundando o olhar analítico sobre a repercussão do discurso da Guerra às Drogas na Justiça Juvenil}

Nesta seção, analisam-se os dados cruzados de duas variáveis, agrupando-as com o escopo de alcançar dados mais qualificados. O cruzamento das variáveis permite interrelacionar e aprofundar o olhar analítico sobre o objeto ora investigado.

\subsubsection{Ano de publicação da decisão e aplicação da Súmula 492 do STJ}

A análise cruzada dessas duas variáveis (ano de publicação dos acórdãos e observância da Súmula 492 do STJ) mostra-se relevante na medida em que possibilita identificar a incorporação do entendimento consolidado do STJ por parte dos Tribunais de Justiça, desde o ano de sua publicação até o ano 2014. 
Tabela 8 - Ano e Aplicação da Súmula 492 do STJ

\begin{tabular}{cccc}
\hline & Sim & Não & 334 \\
$\mathbf{2 0 1 2}$ & 10 & 324 & 210 \\
$\mathbf{2 0 1 3}$ & 11 & 199 & 252 \\
$\mathbf{2 0 1 4}$ & 17 & 235 & $\mathbf{7 9 6}$ \\
\hline Total & $\mathbf{3 8}$ & $\mathbf{7 5 8}$ & \\
\hline
\end{tabular}

Fonte: os autores.

Conforme a Tabela 8, do ano 2012, 334 decisões foram analisadas pela presente pesquisa. Dessa totalidade, apenas 10 decisões aplicaram a Súmula 492 do STJ. Esse percentual representa 3\% da totalidade. No ano 2013, esse percentual eleva-se para 5,2\%. Já no ano 2014, o percentual eleva-se para 6,74\%. Ressalte-se que a Súmula foi publicada em 13 de agosto de 2012, logo, a porcentagem desse ano restou prejudicada, uma vez que se tem como parâmetro o conjunto das decisões de 2012 no correr de todo o ano. As porcentagens dos anos de 2013 e 2014, respectivamente 5,2\% e 6,74\%, revelam, contudo, uma repercussão ainda tímida da referida Súmula nos Tribunais de Justiça do Brasil.

\subsubsection{Decisões que não fazem referência aos incisos do art. 122 do ECA na aplicação da medida de internação}

Conforme apresentado na seção 4.2.2, 285 decisões analisadas aplicam a medida de internação sem se fundamentar expressamente nas hipóteses taxativas do art. 122 do ECA. O cruzamento dessa variável com determinadas variáveis na presente pesquisa mostra-se bastante relevante, na medida em que permite identificar quais os fundamentos que conduziram a Justiça Juvenil à aplicação de medida mais rigorosa, já que não houve remissão explícita às hipóteses legais.

\subsubsection{Gravidade abstrata e Decisões que não fazem referência aos incisos do art. 122 do ECA na aplicação da medida de internação}

Verifica-se do cruzamento dessas variáveis que 72,2\% das decisões que aplicam a medida de internação sem fazer referência a nenhum dos incisos do art. 122 do ECA fundamentam a adoção da privação da liberdade na gravidade abstrata do crime de tráfico de drogas. Essa porcentagem significa que das 285 referidas, 206 delas evocam a gravidade abstrata para justificar o tratamento mais rigoroso possível ao ato infracional análogo ao tráfico de drogas. 


\subsubsection{Proteção da Ordem Pública e Decisões que não fazem referência aos incisos do art. 122 do ECA na aplicação da medida de internação}

Verifica-se do cruzamento dessas variáveis que 23,8\% das decisões que aplicam a medida de internação sem fazer referência a nenhum dos incisos do art. 122 do ECA fundamentam a adoção da privação da liberdade na "proteção da sociedade e da ordem pública." Das 285 decisões que não fazem qualquer menção às hipóteses do art. 122 do ECA, 68 delas evocam a afirmativa dessa variável para justificar a aplicação da medida de internação. Os dados revelam aqui uma mudança do foco daquilo que estabelece o ECA. Prevalece a postura encarceradora fundamentada numa afirmação vaga e que ignora as condições objetivas do adolescente ou a pretensão ressocializadora e excepcional da medida de internação.

\subsubsection{Punição Moral do tráfico e Decisões que não fazem referência aos incisos do art. 122 do ECA na aplicação da medida de internação}

Cruzando essas variáveis, tem-se que das 285 decisões que aplicam a medida excepcional de privação de liberdade sem lastro no art. 122 do ECA, em 138 acórdãos, que representam 48,9\% dessa totalidade, evoca-se ideia de condenação moral da atividade do tráfico para fundamentar a adoção da medida mais severa. Ressalte-se que o tratamento moral sobre o tráfico de drogas afasta o julgador do caso concreto e da própria legislação pertinente para, baseando-se na condenação moral das drogas e, especialmente, de seu comércio ilícito, aplicar as medidas mais severas de que dispõe o sistema punitivo de controle. Essa é, indubitavelmente, uma das principais repercussões do discurso da Guerra às Drogas no tratamento penal da droga.

Indicando o cruzamento da variável Quando da aplicação da medida de internação, qual o inciso do Art. 122 é utilizado para fundamentar tal medida? com as remissões à "gravidade abstrata do tráfico", à "proteção da sociedade e da ordem pública" e à "punição moral" do tráfico é possível delinear algumas respostas para o tratamento excepcional conferido ao tráfico de drogas.

Por fim, vale sublinhar que há uma percentagem bastante expressiva das decisões que aplicam medida de internação sem lastro nas hipóteses do art. 122 que, aliadas com as variáveis que denotam o tratamento rigoroso do tráfico de drogas de modo geral, fazem remissão a concepções típicas da Doutrina Menorista, como a ideia de que a privação de liberdade consiste em forma de proteção (e não em medida extrema que viola o direito de ir e vir) e que a internação representa a medida que mais contribuirá para a ressocialização dos adolescentes, não obstante a violação ao direito de convivência familiar e comunitária. Desse modo, a condensação do discurso de Guerra às Drogas com as permanências da Doutrina Menorista na atuação da Justiça Juvenil tem representado uma totalidade discursiva marcadamente punitivista e encarceradora no Brasil. $\bigcirc$ Gráfico 2 traz a representação dessa totalidade discursiva. 
Gráfico 2 - Fundamentos utilizados pelas 285 decisões que não se referenciam expressamente no art. 122 do ECA para aplicar a medida de internação

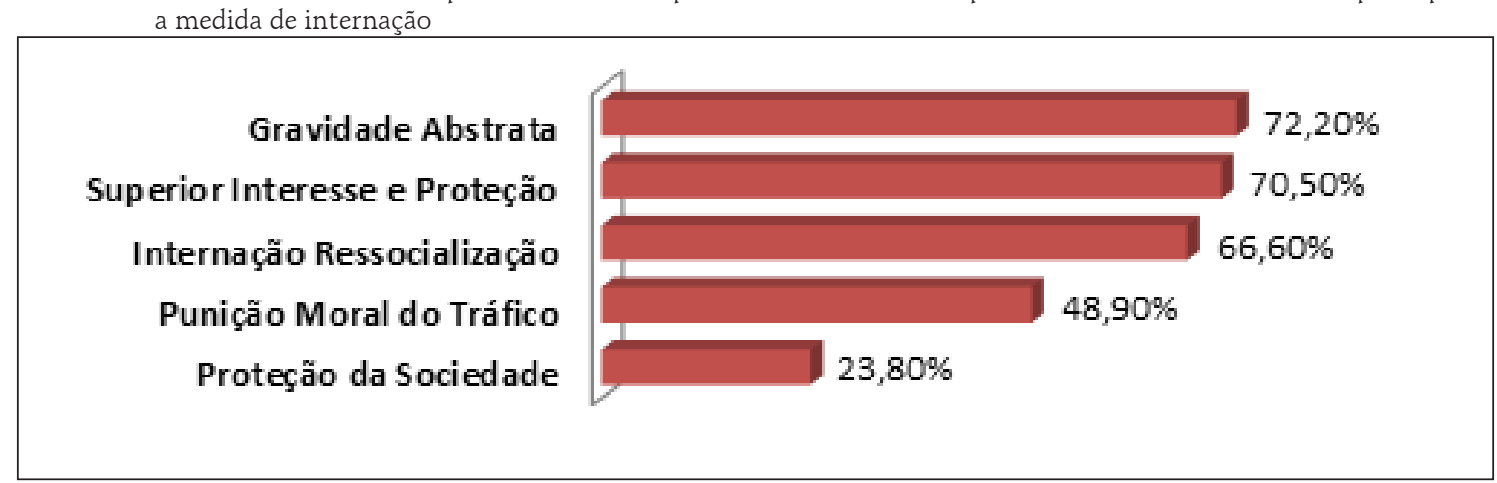

Fonte: os autores.

Pelo Gráfico 2, têm-se as seguintes conclusões: das 285 decisões que não se referenciam expressamente nas hipótese do art. 122 do ECA para aplicar a medida de internação, 72,20\% evocam a "gravidade abstrata" do tráfico; 70,50\% evocam a proteção do adolescente; 66,66\% evocam a ideia da medida de internação como a mais adequada para a ressocialização; 48,90\% evocam a "punição moral" da atividade do tráfico de drogas; e 23,8\% evocam a "proteção da sociedade ou da ordem pública".

\section{Conclusão}

A Constituição Federal de 1988, o Estatuto da Criança e do Adolescente e os diversos normativos internacionais consagram o direito fundamental humano de crianças e adolescentes de apenas excepcionalmente e como último recurso terem sua liberdade privada quando da prática de ato infracional. No Texto Constitucional, tal direito expressa-se no Princípio da Excepcionalidade quando da aplicação da medida socioeducativa de internação. Já na Convenção Internacional sobre os Direitos da Criança das Nações Unidas tem-se o estabelecimento da "detenção" e da "prisão" de crianças e adolescentes apenas como último recurso, estando vedada a "prisão arbitrária e ilegal". Na presente investigação demonstrou-se que esse direito humano tem sido reiteradamente inobservado pela Justiça Juvenil no Brasil em face do ato infracional análogo ao tráfico de drogas.

As pesquisas publicadas pelo CNJ no ano 2012 e pelo Ministério de Direitos Humanos em 2016 acerca do atendimento socioeducativo no Brasil apontam que o tráfico é o segundo ato infracional que mais enseja a aplicação da privação de liberdade de adolescentes no País. Verifica-se, desse modo, rigoroso processo de hiperinternamento de adolescentes acusados de ato infracional análogo ao tráfico de drogas, em dissonância com o Princípio da Excepcionalidade da privação de liberdade de crianças e adolescentes. 
A política criminal de drogas engendrada pelo discurso da Guerra às Drogas, que se forja nas últimas décadas nos Estados Unidos e que se transnacionaliza para a América Latina e para o Brasil de modo especial, estabelece relação direta com essa alta taxa de aplicação da medida de internação. A pesquisa jurisprudencial empreendida no presente trabalho delineia com rigor técnico essa relação, na medida em que problematiza o que poderia justificar a aplicação da medida de internação em acórdãos que elegem tal medida sem respaldo no rol taxativo do art. 122 do ECA, conforme supramencionado.

O cruzamento dos dados assinala que, na ausência de hipótese legal que justifique a medida de internação, emerge a remissão a conceitos e subterfúgios bastante pertinentes ao discurso da Guerra às Drogas e à sua política criminal: 72,20\% das 285 decisões sem respaldo legal nas hipóteses do art. 122 do ECA evocam a "gravidade abstrata" do tráfico; 66,66\% evocam a ideia da medida de internação como a mais adequada para a ressocialização do adolescente; 48,90\% evocam a "punição moral" da atividade do tráfico de drogas, e 23,8\% evocam a "proteção da sociedade e da ordem pública". Tais dados conformam um resultado relevante para a análise da repercussão de um discurso punitivista e criminalizante nas decisões que tratam do ato infracional análogo ao tráfico.

Efetivamente, ante o adolescente acusado de ato infracional análogo ao tráfico de drogas, evidencia-se a construção de um discurso arbitrário e retributivista, capaz de esvaziar o paradigma da Doutrina da Proteção Integral para consolidar uma autêntica prática de hiperencarceramento atualmente no Brasil.

A herança ainda bastante presente da Doutrina Menorista e de um tratamento jurisdicional marcadamente tutelar, discricionário e que concebe a institucionalização da criança e do adolescente como medida de proteção, aprofunda ainda mais o quadro de banalização da privação de liberdade do adolescente acusado de tráfico de drogas. Subvertem-se claramente os princípios e orientações da legislação para reverberar práticas que acentuam estigmas e violências contra os adolescentes, sob o aparente e falso argumento de proteção do jovem, da sociedade e da ordem pública.

Os dados também revelam um descompasso entre a jurisprudência sumulada do STJ e as decisões de primeiro grau. A situação implica uma anomalia dentro do sistema processual, na medida em que ignora a autoridade de um tribunal superior e reforça uma discricionariedade ampla das instâncias inferiores em detrimento da aplicação uniforme de uma lei federal. Trata-se de um fenômeno com impactos diretos sobre a vida, a formação e a liberdade de muitos jovens, com reflexos em milhares de famílias. Ao mesmo tempo, os efeitos individuais vêm acompanhados de práticas judiciais que reforçam a imprevisibilidade e o voluntarismo dentro do sistema de justiça. Sem amparo na lei ou em evidências científicas e em clara ofensa à jurisprudência do STJ, ecoa-se, assim, um discurso datado e irracional de guerra às drogas, preso em pressupostos errôneos dos anos 1950, 1960 e 1970. 


\section{Referências}

ALEXANDER, Michelle. The new Jim Crow: mass incarceration in the Age of Colorblindness. New York: The New Press, 2010.

BATISTA, Nilo. Apresentação. In: OLMO, Rosa Del. A face oculta da droga. Tradução Teresa Ottoní. Rio de Janeiro: Revan, 1990.

BATISTA, Nilo. Política criminal com derramamento de sangue. Revista Brasileira de Ciências Criminais, v. 20, 1997.

BATISTA, Vera Malaguti. Difíceis ganhos fáceis. Drogas e Juventude Pobre no Rio de Janeiro. Rio de Janeiro. Revan, 2003.

BRASIL. Conselho Nacional de Justiça. Panorama Nacional - A Execução das Medidas Socioeducativas de Internação. Brasil: CNJ, 2012. Disponível em: <http://www.cnj.jus.br/images/pesquisasjudiciarias/Publicacoes/panorama_nacional_doj_web.pdf>. Acesso em: 07 jun. 2016.

BRASIL. Constituição. República Federativa do Brasil de 1988. Brasília, DF: Senado Federal, 05 out. 1988. Disponível em: <http://www.planalto.gov.br/ccivil_03/Constituicao/ConstituicaoCompilado.htm >. Acesso em: 28 mar. 2017.

BRASIL. Decreto n. 99.710, de 21 de novembro de 1990. Promulga a Convenção sobre os Direitos da Criança Diário Oficial da União, Brasília, DF, 22 nov. 1990. Disponível em: < http://www.planalto.gov.br/ccivil_03/decreto/1990-1994/D99710.htm>. Acesso em: 28 mar. 2017.

BRASIL. Lei n. 11.343/2006, de 23 de agosto de 2006. Institui o Sistema Nacional de Políticas Públicas sobre Drogas - Sisnad; prescreve medidas para prevenção do uso indevido, atenção e reinserção social de usuários e dependentes de drogas; estabelece normas para repressão à produção não autorizada e ao tráfico ilícito de drogas; define crimes e dá outras providências. Diário Oficial da República Federativa do Brasil, Brasília, DF, 24 ago. 2006b. Disponível em: <http://www.planalto. gov.br/ccivil_03/_ato2004-2006/2006/lei/111343.htm>. Acesso em: 27 mar. 2017.

BRASIL. Lei n. 8.069, de 13 de julho de 1990. Dispõe sobre o Estatuto da Criança e do Adolescente e dá outras providências. Diário Oficial da União, Brasília, DF, 16 jul. 1990a. Disponível em: <http://www.planalto.gov.br/ccivil_03/leis/18069.htm>. Acesso em: 07 jun. 2017.

BRASIL. Lei n. 8.072, de 25 de julho de 1990. Dispõe sobre os crimes hediondos, nos termos do art. $5^{\circ}$, inciso XLIII, da Constituição Federal, e determina outras providências. Diário Oficial da União, Brasília, DF, 26 jul. 1990b. Disponível em <http://www.planalto.gov.br/ccivil_03/leis/18072. htm >. Acesso em: 17 mar. 2016.

COSTA, Ana Paula Motta; ARMANIL, Gabriela Fischer. Juventude, Tráfico de Drogas e Política Criminal: uma análise da edição e aplicação da Súmula 492/2012 do STJ. In: ANDRADE, Vera Regina Pereira de; ÁVILA, Gustavo Noronha de; CARVALHO, Gisele Mendes de (Coord.). Criminologias e Política Criminal. Florianópolis: CONPEDI, 2014. Disponível em: < http://publicadireito. com.br/publicacao/ufsc/livro.php?.gt=199>. Acesso em: 20 maio 2016.

DHNET. Regras Minimas das Nações Unidas para a Administração da Justiça, da Infância e da Juventude (Regras de Beijing). 1985. Disponível em: <http://www.dhnet.org.br/direitos/sip/onu/c_a/ lex47.htm >. Acesso em: 28 maio 2015. 
DHNET. Regras Minimas das Nações Unidas Para a Proteção dos Jovens Privados de Liberdade. 1990. Disponível em: <http://www.dhnet.org.br/direitos/sip/onu/c_a/lex46.htm>. Acesso em: 28 maio 2015.

FEITOSA, Gustavo Raposo Pereira; PINHEIRO, José Augusto de Oliveira. Lei do Abate, guerra às drogas e defesa nacional. Revista Brasileira de Política Internacional, v. 55, n. 1, p. 66-92, 2012. Disponível em: <http://dx.doi.org/10.1590/S0034-73292012000100005>. Acesso em: 16 jul. 2018.

INSTITUTO LATINO-AMERICANO DAS NAÇÕES UNIDAS PARA PREVENÇÃO DO DELITO E TRATAMENTO DO DELINQUENTE. Justiça, Adolescente e Ato Infracional: socioeducação e responsabilização. São Paulo: ILANUD, 2006.

LIBERATI, Wilson Donizeti. Adolescente e Ato Infracional: Medida Sócioeducativa é Pena? 1. ed. São Paulo: Juarez de Oliveira, 2003.

MAIOR NETO, Olympio de Sá Sotto. Garantias penais do adolescente autor de ato infracional. In: INSTITUTO LATINO-AMERICANO DAS NAÇÕES UNIDAS PARA PREVENÇÃO DO DELITO E TRATAMENTO DO DELINQUENTE; ASSOCIAÇÃO BRASILEIRA DE MAGISTRADOS, PROMOTORES DA JUSTIÇA E DEFENSORES PÚBLICOS DA INFÂNCIA E DA JUVENTUDE; SECRETARIA DE ESTADO DE DIREITOS HUMANOS; FUNDO DE POPULAÇÃO DAS NAÇÕES UNIDAS (Org.). Justiça, Adolescente e Ato Infracional: socioeducação e responsabilização. São Paulo: ILANUD, 2006.

MINISTÉRIO NACIONAL DE DIREITOS HUMANOS. Levantamento Nacional do Atendimento Socioeducativo ao adolescente em conflito com a Lei, 2018. Brasília: Ministério dos Direitos Humanos, 2018. Disponível em: <http://www.sejudh.mt.gov.br/documents/412021/9910142/Levantamento+SINASE+_2016Final.pdf/4fd4bcd0-7966-063b-05f5-38e14cf39a41 >. Acesso em: 02 jun. 2018.

PAULA, Paulo Afonso Garrido de Paula. Ato infracional e natureza do sistema de responsabilização. In: INSTITUTO LATINO-AMERICANO DAS NAÇÕES UNIDAS PARA PREVENÇÃO DO DELITO E TRATAMENTO DO DELINQUENTE; ASSOCIAÇÃO BRASILEIRA DE MAGISTRADOS, PROMOTORES DA JUSTIÇA E DEFENSORES PÚBLICOS DA INFÂNCIA E DA JUVENTUDE; SECRETARIA DE ESTADO DE DIREITOS HUMANOS; FUNDO DE POPULAÇÃO DAS NAÇÕES UNIDAS (Org.). Justiça Adolescente e Ato Infracional: socioeducação e responsabilização. São Paulo: ILANUD, 2006.

PINHEIRO, Ângela Alencar Araripe. Criança e Adolescente no Brasil: porque o abismo entre a lei e a realidade. Fortaleza: UFC, 2006.

SARAIVA, João Batista Costa. Compêndio de Direito Penal Juvenil: adolescente e ato infracional. 3 ed. Porto Alegre: Livraria do Advogado, 2010.

SUPERIOR TRIBUNAL DE JUSTIÇA. Habeas Corpus n. 213778/RJ Relator: Ministro Gilson Dipp. Órgão Julgador: Quinta Turma. Julgamento em 22 maio 2012. Diário de Justiça eletrônico, 20 nov. 2012a. Disponível em: <https://stj.jusbrasil.com.br/jurisprudencia/21864167/habeas-corpus-hc-213778-rj-2011-0168789-1-stj>. Acesso em: 19 maio 2017. 
SUPERIOR TRIBUNAL DE JUSTIÇA. Habeas Corpus n. 231459 PE. Relatora: Maria Thereza de Assis Moura. Órgão julgador: Sexta Turma. Julgamento em 03 maio 2012. Diário de Justiça, 14 maio. 2012b. Disponível em: <https://stj.jusbrasil.com.br/jurisprudencia/21776742/habeas-corpus-hc-231459-pe-2012-0013044-1-stj/relatorio-e-voto-21776744? ref=juris-tabs > . Acesso em: 19 fev. 2017.

SUPERIOR TRIBUNAL DE JUSTIÇA. Restrição para internação de adolescente infrator é assegurada em nova súmula. 2012c. Disponível em: < https://stj.jusbrasil.com.br/noticias/100032033/restricao-para-internacao-de-adolescente-infrator-e-assegurada-em-nova-sumula $>$. Acesso em: 20 maio 2017.

SUPERIOR TRIBUNAL DE JUSTIÇA. Súmula 492. Órgão Julgador: Terceira Seção. Diário de Justiça eletrônico, Brasília, DF, 13 ago. 2012d. Disponível em: <http://www.stj.jus.br/SCON/sumulas/ toc.jsp?livre $=\mathrm{s} \%$ FAmula $+492 \& \& b=$ SUMU \& thesaurus $=J U R I D I C O \& p=$ true $>$. Acesso em: 07 jun. 2016.

ZAFFARONI, Eugenio Raúl. O inimigo no direito penal. Rio de Janeiro: Instituto Carioca de Criminologia. Revan, 2007.

Data da submissão: 17 de novembro de 2017 Avaliado em: 10 de julho de 2018 (AVALIADOR A) Avaliado em: 12 de junho de 2018 (AVALIADOR B) Aceito em: 10 de julho de 2018 